\title{
Debt Repayment Capacity in the Emerging Markets and Developing Countries: A Literature Review and Future Research
}

\author{
Siti Hajar Samsu \\ Faculty of Business, Economics and Accountancy, \\ Universiti Malaysia Sabah, Sabah, Malaysia. \\ ct_hajar_98@yahoo.com \\ Nor Asmat Ismail \\ Economic Section, School of Social Sciences, \\ Universiti Sains Malaysia, Malaysia \\ norasmat@usm.my

\section{Che Normee Che Sab} \\ Economic Section, School of Social Sciences, \\ Universiti Sains Malaysia, Malaysia \\ csnormee@usm.my
}

\begin{abstract}
This article is a literature review concerning the factors influencing debt repayment capacity in the emerging and developing countries. Findings from torrent of research indicate that various factors has been influenced the debt service payment ability and have a great deal for the fulfillment of the external obligations. In spite of this, limited research has been undertaken to systematically identify the determinants that are significant and attributed to external debt servicing ability of the countries particularly from global shock and political perspectives.

This study, based on findings from previous studies and literature reviews, attempts to initiate and explore the factors that influencing the external debt servicing capacity in emerging markets and developing countries (EMDC's). A literature analysis using a simple instrument based on the theme classification and variables employed to categorize the sectors or indicators of determinants that had been used in the most scholarly work. The literature review results indicate three major variables, which include financial or scale variables; structural or fundamental variables and political variables. Largely, these groups of variables evaluate both the internal sector performance and external sector performance of countries in the long term development. Accordingly, this study divided the variables into specifically six major sectors: (1) External sector; (2) Real sector; (3) Financial sectors; (4) Monetary sector; (5) and Global shocks; (6) Political sector. Furthermore, this paper also discussing the suggestion for future research to explore in details various issues in this research domain.
\end{abstract}

Keywords: External debt servicing capacity; emerging markets; developing countries; political sectors; global shocks

\section{INTRODUCTION}

What are the main factors that determine debt repayment capacity in Emerging Market and Developing Countries (henceforth EMDC's)?. This is a noteworthy question and an increasingly important issue after a chronicle of debt a saga that haunts the world economy with volume one, the great American Subprime crash crisis 2007-2009; volume two the Eurozone crisis debt the end of 2009 -2012 and volume three, the economic forecast of the emerging market bust that started in the year of 2015. Indeed, this experienced has open up the eyes of the world economy, particularly in EMDC's regarding the effects of external debt service on economic activity, economic growth and financial stability in developing countries. In addition, studies have shown that sustainability of external debts has been highlighted in recent years based on research results that indicate debt sustainability is a general characteristic especially of all the Asian Countries (Lau et al, 2013). 
Sustainability is defined that the debt ratio must be kept in line with the capacity of the debtor country to repay its debt obligation. This is important, especially for developing countries that involved in various decisions about public spending, taxation and borrowing (Cassimon et al, 2008). The aim of this paper to examine the economic determinants that potentially have an impact towards external debt service in EMDC's.

According to the banks, the likely scenario that specific countries seldom experienced repayment difficulties is requiring some refinancing or rescheduling. Therefore, the banker believes that the crucial problem is to be able to detect in advance which countries are likely to experience repayment problem and when these difficulties may arise (Eaton et al, 1986). This scenario depicts the importance of debt service payment performance by looking to the determinants that will help or hindrance the repayment capacity of countries. The dependent variable employed in this study is a debt service to exports ratio. Debt service coverage ratio defined as the sum of principal, interest payment and debt repayment divided by the value of exports of goods and services and receipt of primary income from abroad. This variables capture the burden imposed by debt more accurately than other established weighted measures, such as a debt GDP ratio, total debt to export ratio. The debt service ratio can serve as a useful supplementary indicator for the vulnerabilities in the real economy and the financial sector (Drehman and Juselius, 2012). Previous scholarly works also used debt service ratio to measure debt service capacity (William, 1978; Taffler \& Abassi, 1984; Liu, 2000).

Regardless of the level of country income, poor or rich country; developed or developing country as well as the level of indebtedness, the debt servicing issues consistently one of the major debates on the government administrative level for all countries around the globe because countries around the world having similar criteria of macroeconomic determinant in nature when it comes to debt creation and debt servicing issues. It is vital to have this question answered, as they would demonstrate the critical variables that may contribute to debt servicing performance, which would give some picture of the relevancy to promote resources to the sectors that have a significant implications.

This study portrays the critical macroeconomic determinants of external debt service payment in EMDC's through a literature analysis of research on debt service capacity and country creditworthiness. Therefore, the empirical evidence that had been the basis for this study is initiated on the factors that influence the debt servicing capacity. The main objective of this study is to categorize the identified macroeconomic variables or indicators into groups or sectors, in which the variables with similar features are grouped together. These classifications would enable better understandings on the critical determinants contributes to external debt servicing capacity.

Apart from focusing on the economic indicators determinant, this study will also give an attention and intentionally investigate the external sector and global shocks variables that continuously have negative effects worldwide. For the purpose of this paper, debt service coverage is a ratio that depicts a country credit risk in servicing its external obligations refer to external debt. Therefore, this study specifically analyzes the macroeconomic determinants that potentially have a significant impact on external obligations of a country's. The following sections provide a method of analysis, brief description of the variables and review of the determinants.

\section{METHOD OF ANALYSIS}

The literature analysis was carried out using a simple tool, which was based on the mechanism of macroeconomic indicators theme classification. Thematic classification is the method of sorting the variables employed in the literature so that the economic indicators or variables on a given sector can be documented separately from other variables appropriate to the sector category.

Table 1 was used to arrange and organize the analyses. This type of arrangement originally utilized by UlHaque et al (1998) to study the determinants of a country creditworthiness or country risk. There are three columns in the Table The first column identifies the theme or variables category, while the second column is the variety employed that defines the proxy of the variable selection. The final column is the explanation of the variables, whereby this column is referred to the specific and expected outcome or relationship between the dependent variable and independent variables.

The type of data that investigated was a secondary data from a well-established international institution and most of the findings from the literature are mainly research based. The scholarly works in the literature that examined embodied various factors and economic indicators of external debt 
servicing capacity. The literature consists particularly research published in the journals and books, research published in online journals and research published on Web sites. This empirical evidence basically a quantitative data that reported. Thus, the summarized and general conclusion presented the significance of overall findings.

\section{FINDINGS}

With the three major classification theme of variables based on the literature, the analysis yielded six economic sectors of determinants that influenced external debt service performance: (1) external sector; (2) real sectors; (3) financial sectors; (4) monetary sector; (5) global shocks; (6) political sectors. It has emphasized here that these economic indicators are certainly not the only categories of determinants. It is a potential possibility that there are may be others unintentionally overlooked by the researcher due to vast and the rapid progress of research undertaken these days to explore debt servicing issues. They are numerous economic, political and social factors that are the cause of debt servicing difficulties. However, most of the social factors are not quantifiable and therefore this study limit the economic factors that are quantifiable and regularly published which is in line with earlier studies.

Furthermore, debt servicing capacity issues are not new for sustainable public finance perspectives, but it is a growing research area that needs to be highlighted and explored in such positive manner to achieve sustainability of debt management in all countries. As this article is being written, the debt crisis issues are being investigated and operated in almost every part of the region in the world.

Table1. Summary of economic determinants

\begin{tabular}{|c|c|c|}
\hline Economic determinants & Explanatory variables & Criterion \\
\hline Real sector & $\begin{array}{l}\text { GDP Percapita } \\
\text { External debt to GDP } \\
\text { Fiscal deficit }\end{array}$ & $\begin{array}{l}\text { This category of variables is long term and } \\
\text { solvency variables. It indicates a lower GDP } \\
\text { Percapita, the large fiscal deficit and higher } \\
\text { debt burden suggest the country's debt } \\
\text { burden will become difficult to service over } \\
\text { time and vice versa. }\end{array}$ \\
\hline Monetary sector & Domestic Credit to GDP & $\begin{array}{l}\text { This variables played an important role in } \\
\text { determining the external borrowing flows to } \\
\text { emerging and developing market economies. }\end{array}$ \\
\hline External sector & $\begin{array}{l}\text { Current account balance } \\
\text { Export } \\
\text { Import } \\
\text { Real Trade openness } \\
\end{array}$ & $\begin{array}{l}\text { This group of variables is crucial trade } \\
\text { factors that normally vulnerable to external } \\
\text { shocks when it comes to servicing their debt. } \\
\text { Most of these factors are liquidity variables. }\end{array}$ \\
\hline Global shock & $\begin{array}{l}\text { Term of trade (TOT) } \\
\text { Real effective exchange rate }\end{array}$ & $\begin{array}{l}\text { This group of variables relates to those that } \\
\text { capture external shocks to the economy. }\end{array}$ \\
\hline Financial sector & $\begin{array}{l}\text { Quality investment } \\
\text { International reserves }\end{array}$ & $\begin{array}{l}\text { This group of financial indicators relates to } \\
\text { the sources that the foreign debt has to be } \\
\text { serviced out via international reserves and } \\
\text { capital inflows of FDI so that it's not } \\
\text { depending on the fund from abroad. For this } \\
\text { reason, low international reserves, low } \\
\text { quality investment sharply increases the risk } \\
\text { of default. }\end{array}$ \\
\hline Political sector & $\begin{array}{l}\text { Inflation rate } \\
\text { Quality governance }\end{array}$ & $\begin{array}{l}\text { This variable relates to a structural problem } \\
\text { with government finances and governance. } \\
\text { Public dissatisfaction might generate } \\
\text { political instability. }\end{array}$ \\
\hline
\end{tabular}

\subsection{External Sector}

\subsubsection{Export}

Most of the external sector variables are liquidity variables which are related to short term ability to pay its debt. For examples export of good and services as well as an import for good and services. Lahiri and Dinh (1996) confirmed that export, import, income inequality, inflation and efficiency of investment are able to explain almost 85 percent of the cross country variation in debt servicing 
performance using a panel data of 57 less developing countries includes African, Latin American, Asia, Middle East and Europe. Based on the fact that exports may have a different effect compared to imports, so that we separated these two variables.

Exports are expected to contribute positively to debt service capacity as exports generate income inflows inside the country's, particularly in terms of foreign currencies. Exports can serve as comforting elements in providing the resources for being external debt solvent. Obviously, external debt is denominated in foreign currencies that a must to be serviced by inflows of foreign currencies. Countries having a high export growth rate are expected to be more creditworthy because exports are the primary source of foreign currency inflows and indeed it is having a significant influence on the capacity of the borrowing because of private sector effect and ultimately trigger a declining repayment effect.

\subsubsection{Import}

Based on the fact that most of the developing countries are net importers in the world, it is anticipated that the effect of imports would be more critical than for exports. Instead, to assess a country's ability to pay is to focus on the ability of the country's international reserves with respect to its import known as import cover. On the other hand, a positive sign may obvious in the relationship due to imports denote resourcing more foreign raw materials to locally production to produce more goods for the export objectives. It explains the justification that the effects of imports more significant that for exports.

It has become clear in the existing theoretical literature, foreign trade has been measured by various indicators include inter alia export, import, trade openness, current account and trade liberalization, with positively have an impact on economic growth. This positive relationship has been confirmed by some scholarly works such as (Zafar et al., 2015; Musila \& Yiheyis, 2015) that claimed that trade liberalization is appearing as the universal remedy for growth as what belief by global institutions such as the World Bank, International Monetary Fund (IMF) and World Trade Organization (WTO).

\subsubsection{Current Account Balance}

It is well known that current account balance is one of the solvency variables for one countries. Indeed, persistent current account deficits generate a growth in foreign indebtedness, which may unsustainable in the long term. In other words, a large current account deficit seems that the country relies largely on external funds from outside the host country. The short term liquidity position of a country is an indicator for an early warning sign for any country risk evaluation. Moreover, the current account can be used a measurement to the external debt sustainability. Clearly, the burgeoning current account deficits and at the same time contracted for an external loan without concrete growth manifesting, thus, the issue of concern are liquidity problems and heightened external vulnerability. Current account deficits (trade deficits) are usually associated with the decline in external debt servicing because countries will have less foreign earning to service the foreign debt.

\subsubsection{Real Trade Openness}

On the other hand, the degree of openness to trade may provide additional regarding the determinants of external debt service in developing economies. Trade openness can relate to both internal demand factors and external supply factors. Indeed, a saga of the debt crisis was associated with a dramatic disturbance in global trade, international banking, and debt level. (Ramlall, 2013). Thus, trade openness and debt service may be related. Generally, we expect a positive relationship between trade openness and debt service capacity. Indeed, if a developing country is more open to trade, that is more globalized and more integrated into the global financial system, a growing ability to borrow from abroad would enable the country to borrow at lower interest rates from foreign markets (Obstfeld, 2012).

On the contrary, the more open economies are more exposed to global shocks originating in their main trading partners; as such their debt service capacity can be strongly affected by such shocks. The degree of openness of a country is said to bring enormous benefit in terms of enlargement in growth rate and increase levels of national income. It is also postulated that the open trade regime is a significant predictor to reduced probability of debt rescheduling (Mc Fadden et al, 1985). The political behaviour of external debt in developing countries indicates exist a strong and positive relationship between the level of external debt, the level of output and degree of trade openness (Colombo \& Longoni, 2009). 


\subsection{Real Sector}

\subsubsection{GDP Percapita}

The real sector indicators are categorized as solvency variables which are related to long term ability to pay its debt. The variables in this category are included as fundamental variables in the assessment of debt servicing performance i.e. GDP per capita and fiscal deficit. Studies have also described that the debt service ratio, reserves to import ratio, debt service payments to capital inflow ratio, GDP growth rate, inflation rate and government deficit to GDP ratio are important indicators of debt servicing capacity for 45 African countries. Most of the variables were financial variables rather than structural variables. Usually, GDP is a measure of the level of country growth and development. It should have a positive relationship between GDP per capita and external debt servicing. (Hammer et al., 2004)

\subsubsection{Fiscal deficit}

A negative fiscal balance or known as fiscal deficit indicates that the government lacks the ability to generate tax revenue to finance current consumption and expenditure and it is including debt service. A weak fiscal position also implies a greater probability that external shocks may badly hit the country's economy. Further evidence of real sector determinants of debt service is using panel data from 60 countries from 1980 to 1993, UlHaque et al. (1996) find strong support for the consistent with the factors used in assessing country performance and as what theoretical literature has stressed as important in determining the capacity and willingness to service external debt. They find that the economic fundamentals, a namely ratio of nongold, foreign exchange, reserve to imports, ratio current account balance to GDP, economic growth, and inflation explain a large amount of the variation in the credit rating. This study employed cluster analysis three rating agencies estimation technique.

\subsubsection{External Debt to GDP}

External debt should lesser a pressure on debt service coverage because the higher the level of external debt stock, meaning that the higher would be the repayment process. Therefore, this will lower the country's debt servicing capacity. The decision of any government to take the form of either domestic borrowing or external borrowing it depend on the difference between government revenue and government spending to finance the fiscal balance. Jayaraman and Lau (2009) assert that external borrowing should be channeled into growth-oriented investment. On the contrary, the ratio of a country's external debt to GDP is postulated to have a negative impact on the debt servicing capacity of a country because the level of debt will explain the net borrowing requirement for government whereas only can be met by reducing available resources or borrow a new resource from the public and thereby to service the debt.

\subsection{Financial Sector}

\subsubsection{Quality of Investment}

Foreign direct investment one of the vital portion of capital flows, especially to developing countries. The potential effect of foreign direct investment (FDI) to the host country's debt service repayment via augmentation effects on economic growth of the host country. It is well known that FDI stimulates exports by promoting the transfer of technology (Findlay, 1978; SH Samsu et al, 2009) and generating more knowledgeable workforce (Kobrin, 2005) via positive spillover effects. On the contrary, Lahiri and Dinh (1996) confirmed that the efficiency of investment and not the level of investment that is important for creditworthiness purposes.

\subsubsection{International Reserves}

The relationship between international reserves and external debt is expected can serve as either substitute or complement. In other words, if an increase in external debt leads to an increase in international reserves act as a complement. In contrary, if external debt substitute for internal reserves if it is used to finance the external payment deficit. For instance, external borrowing is used to finance consumption and investment during the volatile period. A negative relationship is expected between reserves and debt service coverage ratio. The underlying rationale is that reserves influence the level of external debt due to a higher reserve induce EMDC's to take more external debt since they already know that they have a backup in terms of service payments. The positive relationship is expected 
between these variables because the higher the value of international reserves to imports, the lower the risk of default and the higher the credit worthiness (Alexe et al. 2003; Hammer et al., 2004). Also, international reserves work more on the cost side of external borrowing.

\subsection{Monetary Sector}

\subsubsection{Domestic Credit to GDP}

An example of the earlier study by Taffler and Abassi (1984) studying 95 developing countries from 1967 to 1978 from a perspective of country risk of being defaulted. The different estimation procedure and analysis were applied. The authors used operational discriminant models to evaluate a debt servicing problem in developing countries. The results show that the country risk is evaluated by economic performance as reflected in monetary policy indicators (domestic credit/GDP) and debt servicing capacity as measured by the level of debt to export and the capacity to secure new borrowing.

Domestic credit level from the banking sector encourages a higher output and provides employment opportunities. Thus, it also reflect that a possibility of higher tax revenues for the government and this result will reduce the requirement for external debt borrowing. In other words, reduced level of external debt stock translates into a lower debt repayment that explains positive effect on debt service capacity. Meanwhile, a negative effect on debt service generates higher public sector borrowing because of private sector effect and ultimately trigger a declining repayment effect.

\subsection{Global Shocks}

\subsubsection{Term of Trade}

Along with the fundamental explanatory variables discussed above, this study focuses on global uncertainty and perceived global risk indicators to control for the impact of global economic and financial market conditions on debt service performance in EMDC's. This research used terms of trade indicators for a proxy of global uncertainty and real effective exchange rate as a proxy of financial environment disturbance. Country's terms of trade defined as the relative price of its exports to imports, which not only may disturb the economic growth but also may introduce substantial instability. Several studies have been examined the impacts of the term of trade on macroeconomic stability.

\subsubsection{Real Effective Exchange Rate}

On the other hand, this study also considers the real effective exchange rate as a predictor variable in determining the external debt service capacity in EMDC's. Furthermore, it is important to note that a fall in the value of the official exchange rate denotes depreciation of the domestic currency, which will lead to an increase in the debt service payment. The real effective exchange rate also is a policy related variables and it is estimated to have an impact on countries creditworthiness and debt servicing capacity.

\subsection{Political Sector}

\subsubsection{Inflation Rate}

Variables which relate to the political situation of a country were incorporated in the creditworthiness study as they assumed political instability have the power to influence the decision for external borrowing and capital flight issues in the home country. A study on the relative importance of political, economic variables in creditworthiness rating explores by UlHaque et al. (1998) using three rating agencies shows that creditworthy is determined primarily by economics variables. The political events can improve the explanatory power of creditworthy level, but the exclusion of political variables does not bias the effects of economic variables.

Apart from that, an economist Kohlscheen (2010) using a sample of 53 emerging economies, data from 1980 to 2005, find robust evidence that possibility of default is influenced by economic and political aspect. When the external debt servicing burden high at a low level of growth rates, with more political power at the head of government, there is propensity to lead more breaks of international repayments promises. In this study, the inflation rate was chosen as a proxy of political instability because a high inflation rate in the domestic market will trigger public dissatisfaction that indirectly will generate political instability. Usually, high inflation rate results in a significant reduction in consumers' purchasing power and also political discontents. (UlHaque et al. 1996; Hammer at al., 2004) 


\subsubsection{Governance Quality}

Corruption can be damaging for an economy through reduce growth, discourage investment, reduce foreign direct investment and limit productivity. Corruption is an acceptable proxy for governance quality that might affect the government expenditure. Accordingly, if a government, finance its expenditure with an increase debt and at the same time there is an event of corruption, thus, a higher stock of debt will lead to higher costs of servicing debt repayment. Cooray and Schneider (2013) suggest that corruption leads to an increase in public debt. The quality of governance can be assessed with the control of corruption and the level of democracy. The quality of governance seems as a factor influencing the relationship between external debt and economic growth in a panel of 72 developing countries over the 1970-2005 period. In other words, countries with lower corruption seem to be able to use and manage their debt better (Jalles, 2011).

\section{Future Research}

Finally, there are needs for future research to examine the causal relationships between the predictor variable and response variables. Most prior research in the debt servicing problems domain has treated economic, financial and politics variables as direct predictors of debt servicing capacity. However, we know from other research that these variables are causally related. For example, Karagol (2012) has demonstrated that exist the unidirectional causal relationship between debt service and GNP level. Apart from that, Saad (2012) also has shown that the real sector variable like export and GDP have a unidirectional granger causality run from external debt service and export and an unidirectional causality between GDP and external debt service.

In retrospect, future research also needs to carefully examine the long run effect between outcome variables and predictor variables by using more innovative methodology to capture the dynamics effect of debt servicing in the long run development process. Previous scholarly works lacking this elements when we consider the time effects and the role of debt in the long run economic process. As we aware that total external debt is consists of short term and long term components, future research also might investigate the potential effects of different types of debt such as short term debt and long term debt, and the differences in the impacts between external and domestic debt towards economic growth. Another interesting direction for future research would be to examine the role debt management strategies when evaluating countries debt servicing capacity. There also are several important methodological issues that need to be taken into account in future research. Another important methodological concern is the need for future research to obtain better evidence for the relationship between debt servicing capacity and their consequences.

\section{Conclusion}

The abundance of earlier research and studies of debt servicing capacity that have been carried out, or are being carried out at the moment shown the set of significant determinants is sensitive to the differences in predictor variables employed, estimation technique used, the data set and also influenced by country specific effects. However, to be the finding meaningful and conclusive further research in the area of debt service capacity must be constantly alert, especially with the newly developed quantitative technique, financial development, policy adjustment and institutional development. There also are several interesting direction for future research domain highlighted in this paper especially on the methodological concern and sample employed to obtain a robust evidence when economy enters the so called globalized world.

The conclusion of this paper also has distinctive implications for policy makers, investors, debtors, and creditors. It appears that in the previous scholarly works fundamental assessment definitely matters in the determinants of risk premium of external borrowing (Rowland and Torres, 2004). Therefore, recommendation for policy makers in EMDC's would pay attention to the macroeconomic sectors that seem to be the most relevant influencing debt service capabilities. This study investigates the factors that play an important role in the external debt servicing capacity in EMDC's. Predominantly, two strong factors that originate from within the country (internal sector performance) and factors those outside the country (external sector performance) intensely influenced the debt servicing capacity. 


\section{REFERENCES}

[1] Lau, E., Baharumshah, A. Z., \& Soon, S. V. (2013). The behavior of external debt in Asian countries: evidence based on panel unit root tests. Journal of Business Economics and Management, 14(sup1), S377-S394.

[2] Cassimon, D., Moreno-Dodson, B., \& Wodon, Q. (2008). Debt Sustainability for Low-Income Countries: A review of standard and alternative concepts.

[3] Eaton, J., Gersovitz, M., \& Stiglitz, J. E. (1986). The pure theory of country risk. European Economic Review, 30(3), 481-513.

[4] Drehmann, M., \& Juselius, M. (2012). Do debt service costs affect macroeconomic and financial stability?. BIS Quarterly Review September.

[5] Williams, A. O. (1978). External debt-servicing capacity in developing countries. The Review of Black Political Economy, 9(1), 79-89.

[6] Taffler, R. J., \& Abassi, B. (1984). Country risk: A model for predicting debt servicing problems in developing countries. Journal of the Royal Statistical Society. Series A (General), 541-568.

[7] Liu, W. (2000). An empirical study of Asian financial crisis by debt service capacity comparison. Managerial Finance, 26(4), 16-27

[8] Ul Haque, N., Mark, N. C., \& Mathieson, D. J. (1998). The relative importance of political and economic variables in creditworthiness ratings.

[9] Lahiri, A., \& Dinh, H. T. (1996). External debt and creditworthiness: theory with evidence. Finnish Economic Papers, 9(2), 110-125.

[10] Zafar, M., Sabri, P. S. U., Ilyas, M., \& Kousar, S. (2015). The impact of trade openness and external debt on economic growth: new evidence from south asia, east asia and middle east.Science International, 27(1).

[11] Musila, J. W., \& Yiheyis, Z. (2015). The impact of trade openness on growth: The case of Kenya. Journal of Policy Modeling, 37(2), 342-354.

[12] Ramlall, I. (2014). The Impact of the Subprime Crisis on Global Financial Markets, Banks and International Trade: A Quest for Sustainable Policies. Cambridge Scholars Publishing.

[13] Obstfeld, M. (2012). Financial flows, financial crises, and global imbalances. Journal of International Money and Finance, 31(3), 469-480.

[14] McFadden, D., Eckaus, R., Feder, G., Hajivassiliou, V., \& O'Connell, S. (1985). Is there life after debt? An econometric analysis of the creditworthiness of developing countries. International debt and the developing countries, 179-209.

[15] Colombo, E., \& Longoni, E. (2009). The Politics of External Debt in Developing Countries (No. 176).

[16] Hammer, P. L., Kogan, A., \& Lejeune, M. A. (2004). Country risk ratings: statistical and combinatorial non-recursive models. Rutgers University Center for Operations Research.

[17] Ul Haque, N., Mark, N. C., \& Mathieson, D. J. (1996). The economic content of indicators of developing country creditworthiness.

[18] Jayaraman, T. K., \& Lau, E. (2009). Does external debt lead to economic growth in Pacific island countries? Journal of Policy Modeling, 31(2), 272-288.

[19] Findlay, R. 1978. Relative Backwardness, Direct Foeign Investment and the Transfer of Technology: A simple Dynamic Model. Quaterly Journal of Economics 92: 1-16.

[20] Samsu, S. H., Derus, A. M., Ooi, A. Y., \& Ghazali, M. F. (2009). Causal links between foreign direct investment and exports: evidence from Malaysia. International Journal of Business and Management, 3(12), p177.

[21] Kobrin, S. J. (2005). The determinants of liberalization of FDI policy in developing countries: a cross-sectional analysis, 1992-2001. Transnational Corporations, 14(1), 67-104.

[22] Alexe, S., Hammer, P. L., Kogan, A., \& Lejeune, M. A. (2003). A non-recursive regression model for country risk rating. RUTCOR-Rutgers University Research Report RRR, 9, 1-40.

[23] Kohlscheen, E. (2010). Domestic vs external sovereign debt servicing: an empirical analysis. International Journal of Finance \& Economics, 15(1), 93-103. 
[24] Cooray, A., \& Schneider, F. (2013). How does corruption affect public debt? An empirical analysis (No. 1322). Working Paper, Department of Economics, Johannes Kepler University of Linz.

[25] Jalles, J. T. (2011). The impact of democracy and corruption on the debt-growth relationship in developing countries. Journal of Economic Development, 36(4), 41.

[26] Karagol, E. (2012). The causality analysis of external debt service and GNP: The case of Turkey. Central Bank Review, 2(1), 39-64.

[27] Saad, W. (2012). Causality between economic growth, export, and external debt servicing: the case of Lebanon. International Journal of Economics and Finance, 4(11), 134.

[28] Rowland, P., \& José Luis Torres T. (2004). Determinants of Spred and Creditworthiness for Emerging Market Sovereign Debt: A Panel Data Study. Banco de la República. Subgerencia de Estudios Económicos. 